\section{Løgstrups disputats genudgivet}

K. E. Logstrup: Den erkendelsesteoretiske konflikt mellem den transcendentalfilosofiske idealisme og teologien, med efterskrift af Kees van Kooten Niekerk, Klim, 2011 [1942], 359 sider, $299 \mathrm{kr}$.

Efter at forlaget Klim har overtaget rettighederne til Løgstrups værker, bliver der gjort en fortjenstfuld indsats for at præsentere hele forfatterskabet samlet i Løgstrup Biblioteket, som udover kommenterede genudgivelser af samtlige trykte arbejder også indeholder selvstændige kommentarbind til de vigtigste af disse samt antologier og monografier om Løgstrups tænkning. Under dynamisk redaktion af David Bugge, Michael Nonboe, Camilla Rohde Søndergaard og Peter Aaboe Sørensen udgives der 2-3 bind om året, og alle udgivelser følges op med seminarer, hvor høje deltagertal vidner om en usvækket interesse for Løgstups tænkning.

En af de seneste udgivelser er Løgstrups disputatsafhandling, der blev forsvaret for den teologiske doktorgrad ved Københavns Uni- versitet den 14. januar i krigsåret 1943. I nyudgivelsen er den oprindelige tekst trykt sammen med rettelser og ændringer, som Løgstrup selv har indfort i sit private eksemplar af bogen. Bogen er forsynet med et 68 sider langt, særdeles oplysende og velskrevet efterskrift af Kees van Kooten Niekerk. Disputatsen havde som bekendt en dramatisk forhistorie. Tre gange havde Løgstrup fået et indleveret manuskript forkastet, inden det fjerde gang lykkedes at få afhandlingen antaget til forsvar. Efterskriftet redegør klart og overskueligt for forholdet mellem de fire manuskripter, ligesom der bliver givet en særdeles nyttig oversigt over indholdet af selve disputatsen. Nye læsere kan med fordel begynde med efterskriftet.

Afhandlingens anliggende er teologiens behov for at frigøre sig fra en bestemt filosofisk forståelse af den menneskelige erkendelse, som for Løgstrup at se var kulturelt dominerende i samtiden, og som teologien således også risikerede at ligge under for. Man kunne tro, at det var den naturvidenskabeligt orienterede, positivistiske, erkendelsesteori, Løgstrup havde i tankerne. Det er det imidlertid ikke. 
For ham er hovedmodstanderen den transcendentalfilosofiske idealisme, som repræsenteredes af nykantianere som Heinrich Richert, Hermann Cohen, Ernst Cassirer og Paul Natorp. Det, teologien hverken kan eller bør affinde sig med, er, at denne filosofi gør subjektet og dets fornuft til skaber af al orden, al bestemthed og al sammenhæng i erkendelsen. Når objektet for erkendelsen således gøres til en funktion af subjektet, bliver selve tanken om en gudserkendelse umulig. Inden for rammerne af denne forståelse af subjekt-objekt forholdet bliver gudserkendelse uvægerligt til afgudserkendelse, og uden for gøres Gud til intet - en mystisk, skikkelsesløs "urgrund" for erkendelsen.

I afhandlingens første del diskuterer Løgstrup forskellige forsøg på at løse denne erkendelsesteoretiske konflikt alene med erkendelsesteoretiske midler, men han afviser dem alle som skinløsninger. Det er interessant at se, hvordan han her mener at kunne bruge den empiristiske og positivistiske filosofi som allieret i opgøret med subjektobjekt skemaet, men alt $i$ alt virker meget af diskussionen i første del unødigt detaljeret og på en måde overflødig i forhold til Løgstrups eget bidrag som det udfoldes i anden del. Her kritiserer han den transcendentalfilosofiske idealisme for, at den i grunden aldrig tænker sin egen tanke om subjektet som oprindelsen til erkendelsesobjektets form helt til ende. Man opererer med en forestilling om et spontant skabende subjekt, men gør sig ikke klart, at subjektets tilsyneladende almægtige skabelse, når det kommer til stykket, er ganske afmægtig og aldrig skaber andet end sig selv. Det er den transcendentalfilosofiske idealismes skabelsesbegreb og den dermed forbundne livsopfattelse, der er det teologisk angribelige, og denne livsopfattelse står egentlig ganske ubegrundet og ubegrundelig over for den jødisk-kristne livsforståelse, hvor subjektets liv forstås som skabt med en bestemt form forud for og uafhængigt af, at subjektet i øvrigt kan forme sig selv og sine omgivelser kulturelt. Løgstrup anfører en række livslove, som angiveligt skulle følge af livets skabthed. Den før-kulturelle etiske fordring er her indholdsfyldt på en måde, som han senere indser, at den ikke kan være det.

Han kritiserer videre den transcendentalfilosofiske idealisme for dens monologiske karakter, der er en følge af, at det enkelte subjekt kun kan forstå andre subjekter som en slags objekter. Mange prominente temaer i Løgstrups senere tænkning bliver her udfoldet filosofisk, men også eksplicit kristelig- 
teologisk, både hvad angår gudsforholdet og forståelsen af Jesus. Denne sidste halvdel af anden del er klart den livligst skrevne og mest tilgængelige del af afhandlingen. Hvor første del har præg af akademisk pligtarbejde, har anden del en anderledes friskhed, også hvor den filosofisk set fremstår dogmatisk.

Løgstrups disputatsafhandling er et uomgængeligt værk for enhver, der vil forstå udviklingen i forfatterskabet. Det rummer slående formuleringer og overbevisende argumenter, men betragtet som bidrag til erkendelsesteorien i bred forstand eller til en principiel diskussion af forholdet mellem teologi og filosofi virker det i dag for tidsbundet og uforløst til at være uomgængeligt. Hvis vi ikke havde Løgstrups øvrige forfatterskab, ville der således ikke være grund til at genudgive bogen, men da vi nu har det, er det storartet, at den er blevet gjort tilgængelig i en så veltilrettelagt udgave.

Hans Fink

\section{Til kamp for demokra- tisk oplysning}

Jonathan Israel: Democratic Enlightenment: Pbilosopby, Revolution, and Human Rights, 1750 1790, Oxford University Press, 2011, 1152 sider, $45 U S D$.

I den tredje bog i sin serie om oplysningstænkningen bevæger Jonathan Israel sig fra $1750 \mathrm{og}$ frem til 1790. Israel har i sit samlede oplysningsprojekt givetvis haft Den Franske Revolution som sit klare endemål, og i dette værk træder den endelig frem på scenen. Det betyder dog ikke, at Israel forfalder til teleologisk læsninger af sit materiale; i stedet lader han revolutionen fungere som fortællingens kulisse, der det ene øjeblik er glemt og ignoreret, og det næste træder frem og bliver påtrængende.

Som i sine andre værker om Oplysningen har Israel gang $i$ et voldsomt opgør med den hidtidige historieforskning, der ifølge ham tilskriver filosofien for lidt betydning i den historiske udvikling, og som derfor ender $i$ forskellige afskygninger af reaktionære konklusioner. I stedet insisterer Israel på filosofiens realhistoriske følgevirkninger. Og her er der ifølge Israel dybest set tre typer af filosofi: Moderat oplysning, radikal oplysning og modoplysning, hvor især den 